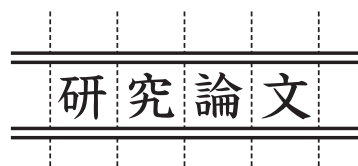

\title{
カーシュレッダーダスト直接溶融飛疢中有害元素の固定化 \\ Immobilization of Harmful Elements in Fly Ash from Direct Combustion of Automobile Shredder Residue
}

\author{
井上 亮* · 有山達 郎* \\ Ryo INOUE* and Tatsuro ARIYAMA*
}

(Received May 25, 2007)

\begin{abstract}
A direct combustion method of automobile shredder residue at high temperature is considered to be an effective process, because the volume of residue can be reduced and many valuable metals can be recovered. However, the fly ash containing large amounts of heavy metals and fluorine are generated inevitably by this process. Therefore, the treatment for detoxification of this fly ash is significantly important. It is found in the present research that cement is effective on the immobilization of harmful elements in the fly ash. The hydrothermal treatment of the solidified mixture of fly ash, cement and water is also superior in the immobilization effect.
\end{abstract}

Key Words: automobile shredder residue, fly ash, heavy metal, fluorine, immobilization

\section{1. 緒言}

世界的な環境問題の高まりを背景に、廃棄物低減やリサ イクルをはじめとして、これまで以上に環境に配慮した社 会システムの構築が急務となっている。このような状況の 中で、現在の使用済み自動車のリサイクル率は 75〜80\% ${ }^{1)}$ 、 使用済み家電品のリサイクル率は約 $50 \%$ 2) であり、さらに 高いリサイクル率が望まれている。使用済み自動車や家電 品から発生するシュレッダーダストは、現在、国内だけで 年間 100 万トンにのぼる3)。シュレッダーダストはプラス チックや繊維類を主体として金属などの不燃物を含む混合 物であるため分別作業が困難である。このため、通常の産 業廃棄物最終処分基準に準じたセメント固化法、薬剤処理 法、酸抽出法または溶融法では適正な処理が難しいことか ら、これまではほぼ全量が最終的に埋め立て処分されてい た。しかし、処分場近辺の地下水污染問題が生じたことか ら、平成 8 年 4 月からは管理型処分場への搬入が義務付け られた。最近、処分場の枯渇やそれに伴う処分費の高騰な どの問題が表面化し、環境に適合した減容化処理技術の確 立が強く望まれている。

このような時流の中で、カーシュレッダーダストを直接 溶融炉において高温で処理する廃棄物直接溶融技術が脚光 を浴びはじめている。廃棄物減容化および有価金属回収が 可能なことから、最も効果的な処理方法とみなされている
が、他方、直接溶融処理の際に不可避的に発生する飛灰中 には重金属 $(0.6 \sim 1 \% \mathrm{~Pb}, 0.01 \sim 0.02 \% \mathrm{Cd}, 0.05 \sim 0.2 \% \mathrm{Cr}$ な ど）やフッ素 $(0.2 \sim 1.6 \%)$ が高濃度に含まれる。特に $\mathrm{Pb}$ は $0.5 \mathrm{mg}$ 以上吸引すると中毒症状を呈し、0.5 $\mathrm{g}$ 以上吸引す ると命にかかわるとされている。また、腎臓、肝臓、骨に 蓄積され、しかも排泄され難いため、長期の摂取によって 機能障害が引き起こされる 4)。また、フッ素は歯牙フッ素 症、骨硬化症、甲状腺障害、腎臓障害の原因となることが 認められている 5), 6)。これらの重大な健康障害を防ぐため に、飛灰の無害化処理法の開発が新たな課題となっている。 本研究は、カーシュレッダーダストを直接溶融処理した 際に発生する飛灰を無害化する技術の開発を目的としてい る。

\section{2. 溶出試験法の問題点}

最終処分された廃棄物が環境污染の原因となることにつ いて最も危惧されていることは、廃棄物中の有害物質が処 分場の外へ拡散することである。廃棄物が降雨や地下水と 接触することにより、廃衰物中の有害物質は溶出し、さら に地下水の流れに乗って処分場の外にまで流出する。これ が一般的な処分場からの有害物質溶出経路である。7), 8)

このような廃棄物からの有害物質溶出の危険性を事前に 評価するために、各国で様々な溶出試験法が提唱されてい る。現在日本で用いられている産業廃棄物処理判定基準の

* 東北大学多元物質科学研究所 ( $=980-8577$ 仙台市青葉区片平 2-1-1)

Institute of Multidisciplinary Research for Advanced Material, Tohoku University (1-1, 2-chome, Katahira, Aoba-ku Sendai 980-8577, Japan) 
ための溶出試験法（環境庁告示 13 号）は、代表的な処分地 を想定し、そこでの溶出条件を溶出試験時に再現すること に主眼をおいているものである ${ }^{8)}$ が、以下の課題を有する。 1) 溶出液の $\mathrm{pH}$ は初期值のみが規定されているに過ぎず、 酸性雨等による低 $\mathrm{pH}$ での溶出は考慮されていない

2) 試料粒径が $0.5 \sim 5 \mathrm{~mm}$ であり粒度分布の規定が無いた め、粗大粒子の割合が高い場合には溶出量が低くなり やすい

3) 固液比が $1 / 10$ であり、他イオンの濃度が上昇しやすい ため溶出值が影響を受けやすい

これに対して、世界一厳しい溶出試験法とみなされてい るオランダの Availability test では、試料粒径 $125 \mu \mathrm{m}$ 以下、 溶出時間 6 時間、溶出液の $\mathrm{pH}$ 4、固液比 $1: 100$ と規定さ れており、廃棄物からの諸物質の溶出を妨げることの無い ように種々の条件を定めた上で廃棄物から溶け出し得る最 大溶出可能量を測定しようというものである ${ }^{8)}$ 。また、土壤 環境基準のための溶出試験法（環境庁告示 46 号）は試料粒 径が $2 \mathrm{~mm}$ 以下である以外は環境庁告示 13 号と同じである が、この場合も粒度分布の規定が無いため、有害物質の溶 出量は試料粒径に反比例する。

本研究では、水に対する物質自体の化学的安定性、すな わち物質の最大溶出量を評価することを目的とし、試料粒 径を主に $105 \mu \mathrm{m}$ (150メッシュ) 以下とした。また、200 回/分で振とうしながら、6 時間だけでなく $0.5 、 2 、 12$ お よび 24 時間でも溶出液を採取し、溶出液中の各イオン濃度 の経時変化から、安定化処理した試料の長期安定性を推測 した。

\section{3. 有害元素固定化の原理}

水和反応によって生成する沈殿物は大別して

1) $\mathrm{CaO}-\mathrm{SiO}_{2}-\mathrm{H}_{2} \mathrm{O}$ 系化合物（非晶質ゲルも含む）

2) (tricalcium-) aluminate ferrite-tri (sulfate, hydroxide, etc.) · hydrate（以下、AFt 相と略称す）

3) (tricalcium-) aluminate ferrite-mono (sulfate、 hydroxide、 etc.) · hydrate (以下、AFm 相と略称す)

4) cubic hydration product

5) simple hydrate

6) apatite

であり、これら水和物中の各イオンサイトと固定化させた い陽イオンや陰イオンが置換することにより安定化が起こ る9)。上記の水和物の生成による有害イオン固定化の中で 効果が大きいのは一般的に (1) ～(4) である。本実験条件下 では、後述するように(1) および (3) の作用が強いとみなさ れたので、これら水和物の生成反応を利用してフッ素およ び重金属を固定化する実験を行った。

\section{4. 実験方法}

\section{1 試料}

本研究ではカーシュレッダーダストを直接溶融炉で焼 却した際に発生した飛灰を対象とした。カーシュレッダー ダスト直接溶融飛灰としては、酸素供給量に比べてカー シュレッダーダスト量が過多の還元性䨌囲気下で発生し残 留 $\mathrm{C}$ 量が多い黒色系 (DFA-1) と、酸素供給量がより多くて 残留 $\mathrm{C}$ 量が少ない灰色系 (DFA-2) がある。これらの組成を Table 1 に与える。黒色系の DFA-1 は残留 C 量が多いこ とから疎水性が強く、水和反応による有害元素の固定化が DFA-2 より困難であると予想される。有害物質の固定剂と して用いた市販ポルトランドセメントおよび高炉スラグセ メント B 種の化学組成も同表中に与える。高炉スラグセメ ント B 種は、ポルトランドセメントに高炉水砕スラグを 30 〜 60\% 混合したもので、化学反応性が高いことから、ポル トランドセメントより長期強度を発現すること 10111) が知ら れている。

\section{2 安定化処理}

カーシュレッダーダスト直接溶融飛灰を篩分けして粒度 を $0.1 \mathrm{~mm}$ 以下とし、セメントおよび石膏と十分に混合し た後に適量の蒸留水を加えて混練して室温で自然凝結させ た。水熱処理を行う実験では、凝結した塊状試料をガラス 容器に入れ、水を滴下した後、オートクレーブ内で $120^{\circ} \mathrm{C}$ 、 $0.14 \mathrm{MPa}$ で $3 \mathrm{~h}$ 処理した。

\section{3 溶出試験}

安定化処理後の試料を大気中で充分に乾燥させた後、メ ノウ乳鉢で粗粉砕し、振動ミルを用いて $0.1 \mathrm{~mm}$ 以下の試料 とした。

Table 1 Chemical compositions of fly ashes, Portland cement and blast furnace slag cement. (mass\%)

\begin{tabular}{|c|c|c|c|c|}
\hline \multirow{2}{*}{} & \multicolumn{2}{|c|}{ Fly ash } & \multirow{2}{*}{$\begin{array}{c}\text { Portland } \\
\text { cement }\end{array}$} & $\begin{array}{c}\text { Blast furnace slag } \\
\text { cement-B }\end{array}$ \\
\cline { 2 - 3 } & DFA-1 & DFA-2 & & 55.3 \\
\hline $\mathrm{CaO}$ & 12.2 & 22.8 & 63.8 & 16.4 \\
\hline $\mathrm{SiO}_{2}$ & 9.1 & 8.1 & 22.1 & 11.9 \\
\hline $\mathrm{Al}_{2} \mathrm{O}_{3}$ & 2.5 & 2.6 & 5.0 & 1.3 \\
\hline $\mathrm{MgO}$ & 0.9 & 1.3 & 1.6 & 1.0 \\
\hline $\mathrm{S}$ & 0.5 & 0.6 & 1.0 & \\
\hline $\mathrm{C}$ & 33.5 & 3.6 & & \\
\hline $\mathrm{Na}$ & 4.2 & 1.0 & & \\
\hline $\mathrm{K}$ & 5.7 & 0.6 & & \\
\hline $\mathrm{Cl}$ & 8.6 & 5.3 & & \\
\hline $\mathrm{F}$ & 0.13 & 0.10 & & \\
\hline $\mathrm{Pb}$ & 0.083 & 0.013 & & \\
\hline $\mathrm{Cr}$ & 0.05 & 0.28 & & \\
\hline $\mathrm{Zn}$ & 0.29 & 0.01 & & \\
\hline $\mathrm{Cu}$ & 0.12 & 0.10 & & \\
\hline $\mathrm{Mo}$ & $<0.01$ & $<0.01$ & & \\
\hline
\end{tabular}




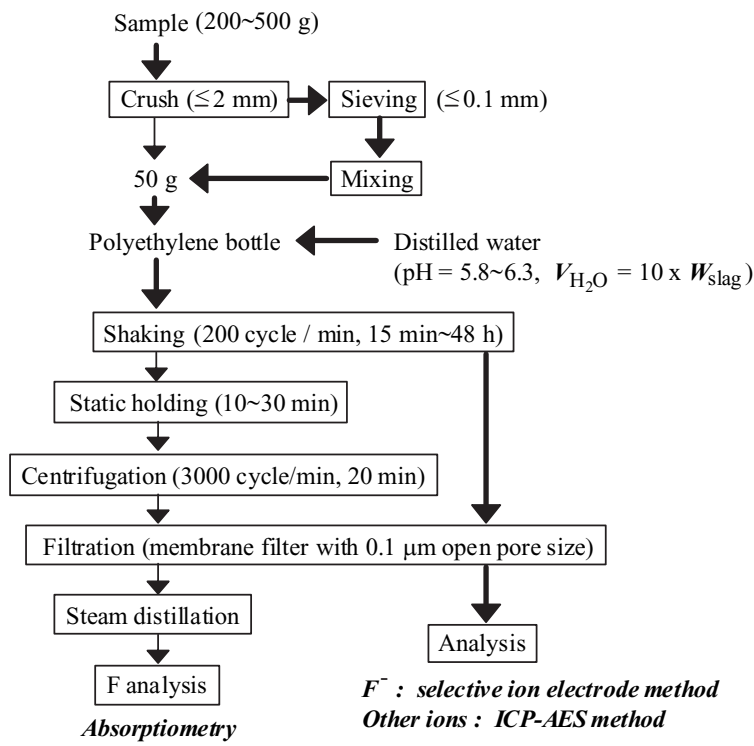

Fig. 1 Flow chart of leaching test used in this work: thin arrow represents the procedure according to the Japanese standard test (codified as Environment Agency Notice 46).

土壤環境基準の判定法として環境庁告示 46 号による溶 出試験が制定されているが、第 2 章で述べたように、この 試験方法には溶出液中のフッ素定量值に大きく影響を与え る因子があることが明らかになったため、Fig.1に示す方 法 ${ }^{12)}$ を用いた。即ち、試料 $50 \mathrm{~g}$ を蓋付きポリエチレンボト ルに入れ、試料重量の 10 倍量の蒸留水を加えて横型振とう 機で毎分 200 回振とう混合した。所定時間毎にポリエチレ ン製ホールピペットにより分取し、メンブランフィルター （開孔径 $0.1 \mu \mathrm{m}$ ）を用いて吸引ろ過して、フッ素分析用ポ リカーボネート製メスフラスコおよび他成分分析用メスフ ラスコのそれぞれに移した後に標線まで希釈した。フッ素 分析用 $100 \mathrm{~cm}^{3}$ メスフラスコには $\mathrm{pH} 5$ に調整したフッ素分 析用緩衝液 $(5.8 \mathrm{w} / \mathrm{v} \% \mathrm{NaCl}-0.4 \mathrm{w} / \mathrm{v} \% \mathrm{CyDTA}-5.7 \mathrm{w} / \mathrm{v} \%$ 酢 酸 - $3.5 \mathrm{w} / \mathrm{v} \% \mathrm{NaOH} ４ 0 \mathrm{~cm}^{3}$ を、他イオン分析用 $10 \mathrm{~cm}^{3}$ メス フラスコには $\mathrm{HNO}_{3}(1+1)$ 溶液 $3 \mathrm{~cm}^{3}$ を予め入れてある。

\section{4 分析}

フッ素分析はフッ素選択イオン電極法 (JIS-K-0101)によ り、他イオン分析は高周波誘導結合プラズマー質量分析装 置 (ICP-MS) または高周波誘導結合プラズマー発光分光分析 装置 (ICP-AES) により行った。

カーシュレッダーダスト直接溶融飛灰とセメントの反応 界面を調べる実験は以下の方法を用いた。まず、DFA-1を $100 \mathrm{~kg} / \mathrm{cm}^{2}$ の圧力で $2 \mathrm{~mm} \phi$ に圧粉成型した。これをポルト ランドセメントと共に $10 \mathrm{~mm} \phi$ の圧粉容器に装入して水を 滴下し、 $100 \mathrm{~kg} / \mathrm{cm}^{2}$ の圧力で再び圧粉成型した後、加圧し ながら $80{ }^{\circ} \mathrm{C} て ゙ 3 〜 10 h$ 保持した。圧粉容器から取り出した 後に自然乾燥し、樹脂に埋め込んだ。これを研磨紙で乾式
Table 2 Environmental quality standards regulated by Ministry of the Environment. (ppm)

\begin{tabular}{|c|c|c|c|}
\hline & Soil & $\begin{array}{c}\text { Waste treatment } \\
\text { (landfill) }\end{array}$ & $\begin{array}{c}\text { Ground } \\
\text { water }\end{array}$ \\
\hline $\mathrm{F}$ & 0.8 & - & 0.8 \\
\hline $\mathrm{Pb}$ & 0.01 & 0.3 & 0.05 \\
\hline $\mathrm{Total} \mathrm{Cr}$ & - & - & - \\
\hline $\mathrm{Cr}^{6+}$ & 0.05 & 0.05 & 0.05 \\
\hline $\mathrm{Zn}$ & - & - & - \\
\hline $\mathrm{Cu}$ & $125 \mathrm{mg} / \mathrm{kg}$ & - & - \\
\hline $\mathrm{Mo}$ & $(0.07)$ & - & 0.07 \\
\hline
\end{tabular}

( ) : Monitoring value.

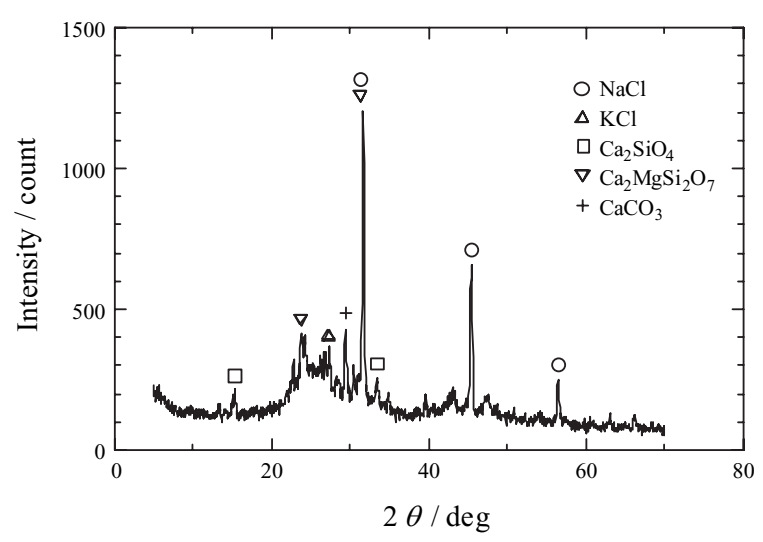

Fig. 2 X-ray diffraction pattern of DFA-1.

研磨した後、カーボン蒸着を行い、EPMA を用いてカーシュ レッダーダスト直接溶融飛灰／セメントの界面観察および 局所定量分析を行った。

\section{5. 実験結果および考察}

土壤環境基準、廃棄物処理判定基準および水質環境基準 における規制值を Table 2 にまとめた。ここで、全 $\mathrm{Cr}$ 溶出 量は規制されていないが、六価 $\mathrm{Cr}$ の規制值が制定されてい ることから、溶出液中で Cr イオンの価数変化が起こり得る7) 可能性を考慮して、本研究における全 $\mathrm{Cr}$ 溶出量の抑制目標 值を六価 $\mathrm{Cr}$ の規制值とした。 $\mathrm{Zn}$ および $\mathrm{Cu}$ については溶 出值は規制されておらず、Mo は現状では要監視項目であ るに過ぎない。このため、本研究では F、 $\mathrm{Pb} 、$ 全 $\mathrm{Cr} 、 \mathrm{Mo}$ の溶出量について検討している。

\section{1 カーシュレッダーダスト直接溶融飛灰からの有害元素 の溶出}

黒色系 DFA-1 の X 線回折の結果を Fig.2 に示す。この図 より、C 以外の主要鉱物相は $\mathrm{NaCl} 、 \mathrm{Ca}_{2} \mathrm{MgSi}_{2} \mathrm{O}_{7} 、 \mathrm{CaCO}_{3}$ で あることがわかる。灰色系 DFA-2 についても同様の結果で 
カーシュレッダーダスト直接溶融飛灰中有害元素の固定化（井上・有山）

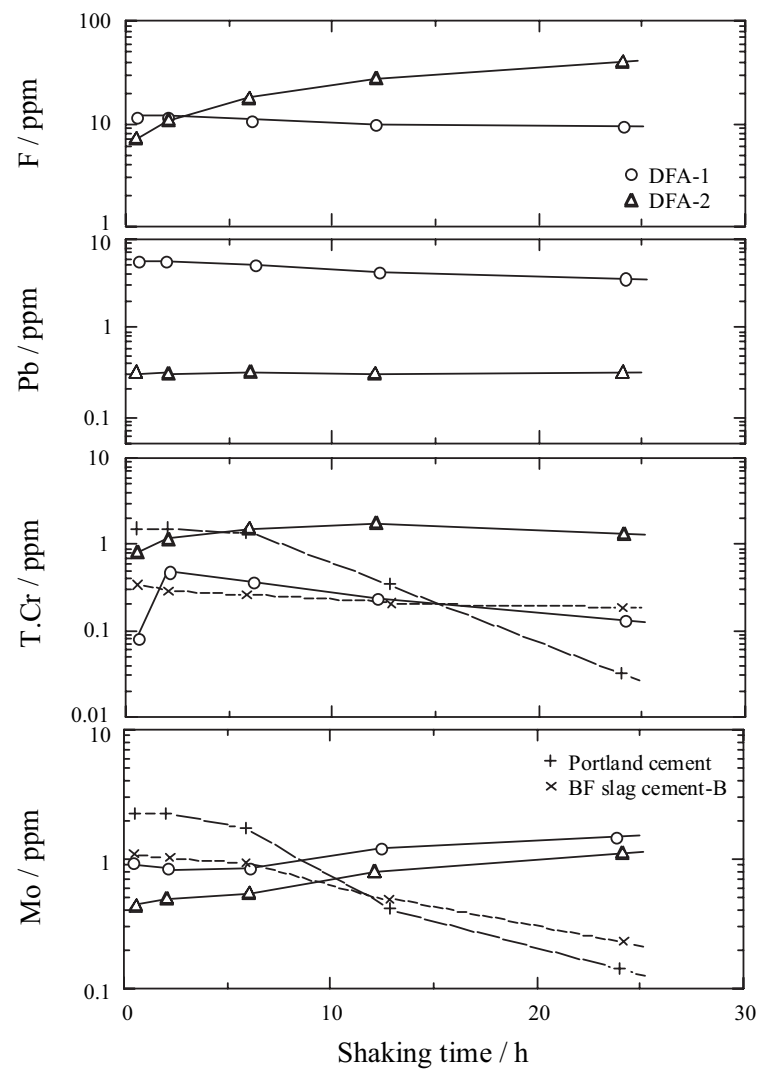

Fig. 3 Variation of $\mathrm{F}, \mathrm{Pb}$, total $\mathrm{Cr}$ and Mo contents in solution dissolved from fly ash and cement with shaking time.

あつた。

$0.1 \mathrm{~mm}$ 以下に篩い分けした黒色系および死色系カーシュ レッダーダスト直接溶融飛灰の溶出試験結果について、 $\mathrm{F} 、 \mathrm{~Pb} 、$ 全 $\mathrm{Cr} 、 \mathrm{Mo}$ の溶出量の経時変化を Fig.3に与える。 DFA-2 からのF および全 Cr 溶出值は DFA-1 より高いが、 その他の元素の溶出値は DFA-1 より低い。いずれの直接溶 融飛灰においても $\mathrm{F} 、 \mathrm{~Pb} 、$ 全 $\mathrm{Cr} 、 \mathrm{Mo}$ （要監視項目）の溶出 量はTable 2 に示した規制值を超えている。同図中にポル トランドセメントおよび高炉スラグセメント B 種の溶出試 験結果を示す。セメントは $\mathrm{MgCr}_{2} \mathrm{O}_{4}$ レンガの内張を有する 加熱炉で焼成されることから、これらセメントから $\mathrm{Cr}$ が溶 出することは予想されたが、Moも溶出している。さらに Znの溶出も認められた。

\section{2 セメントによるカーシュレッダーダスト直接溶融飛灰 の安定化}

都市ゴミ焼却灰の固化に溶融法を用いた場合、溶融処理 中に発生する二次飛灰 (溶融飛灰) 中の重金属濃度はさら に高くなるため、セメント固化法による溶融飛灰の無害化 は困難である ${ }^{13)}$ 。一方、セメント固化法は簡便で安価な無 害化手段であることから、需要が多い。直接溶融炉から排 出される飛灰中の重金属濃度は二次飛灰より低いことに注

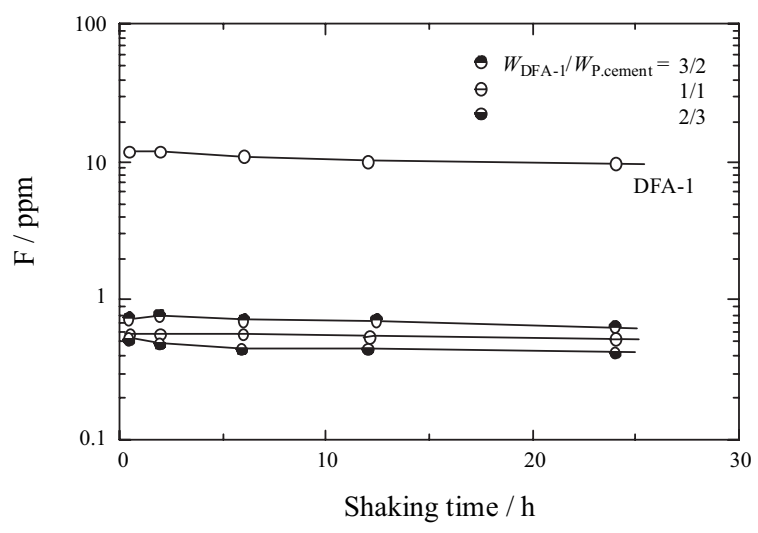

Fig. 4 Effect of addition of Portland cement on F immobilization in DFA-1.

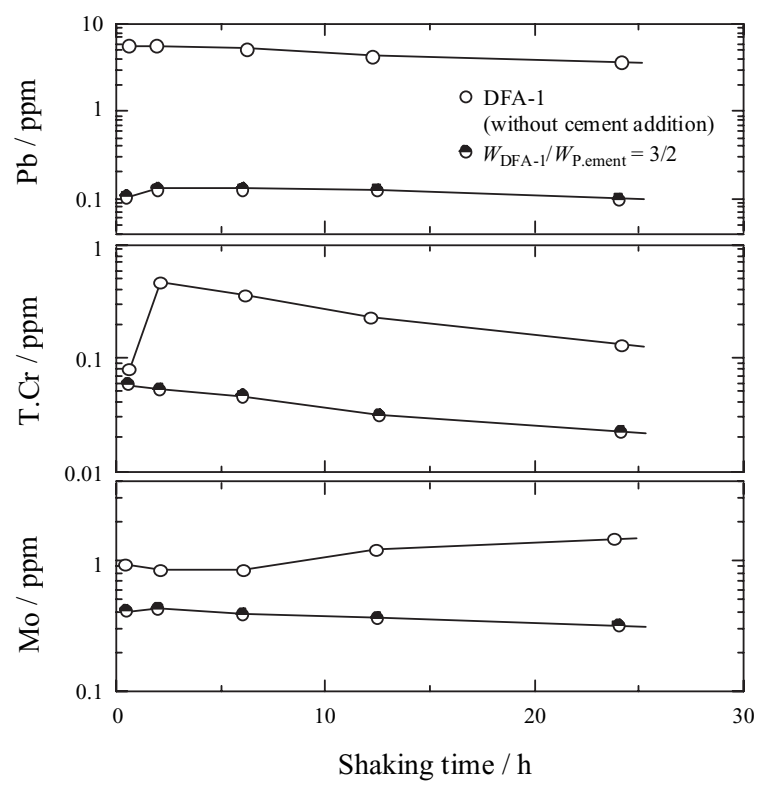

Fig. 5 Effect of addition of Portland cement on $\mathrm{Pb}$, total $\mathrm{Cr}$ and $\mathrm{Mo}$ immobilization in DFA-1.

目し、セメントによるカーシュレッダーダスト直接溶融飛 灰の安定化を試みた。

ポルトランドセメントをDFA-1 と重量比 $3 / 2$ ～2/3 で混 合し、混練後に凝結させた試料についてのフッ素溶出值を Fig.4に示す。いずれの混合比でもフッ素溶出量は著しく 減少し、規制值（振とう6hで $0.8 \mathrm{ppm}$ ）をクリアしている。 ポルトランドセメント量によってフッ素溶出量はほとんど 変化しないが、これはポルトランドセメント／DFA-1 重量 比が $3 / 2$ でもポルトランドセメントが固定化反応に対して 十分な量に達していることを表している。

DFA-1をポルトランドセメントと重量比 3/2 で混合し、 混練後に凝結させた試料についての $\mathrm{Pb}$ 、全 $\mathrm{Cr}$ および $\mathrm{Mo}$ 溶出量の経時変化を Fig.5 に示す。 $\mathrm{Pb}$ 濃度は減少したもの の、規制值（振とう $6 \mathrm{~h}$ で $0.01 \mathrm{ppm}$ ）には達していない。全 


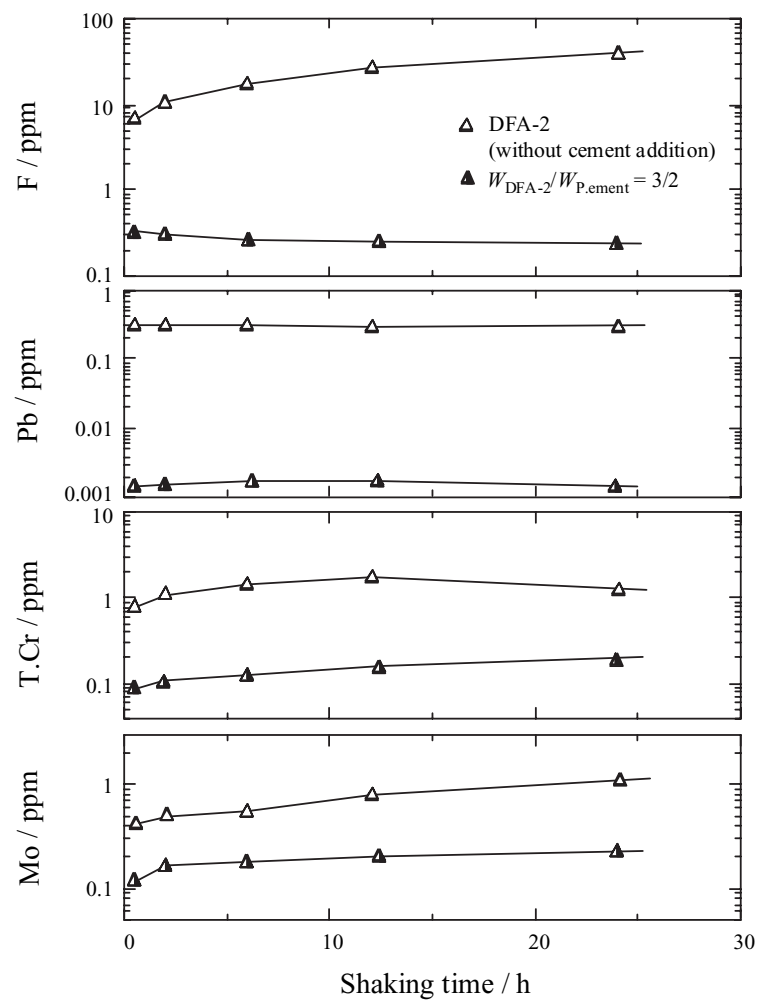

Fig. 6 Effect of addition of Portland cement on $\mathrm{F}, \mathrm{Pb}$, total $\mathrm{Cr}$ and $\mathrm{Mo}$ immobilization in DFA-2.

Cr およびMo 濃度の低下は小さい。黒色系 DFA-1 の代わ りに灰色系 DFA-2 を用いた試料についての溶出試験結果を Fig.6に示す。DFA-1 の結果（Fig.4、5）と比べて全 Cr 以 外の元素の溶出抑制効果は顕著であり、特に $\mathrm{Pb}$ 濃度が規 制值をクリアしている点は注目に值する。セメントによる 固定化機構については 5.6 項で述べる。

\section{3 水熱処理によるカーシュレッダーダスト直接溶融飛灰 の安定化}

黒色系 DFA-1 をポルトランドセメントと重量比 3/2 で混 合し、混練後に凝結させた試料について、120年で $3 \mathrm{~h}$ オー トクレーブ処理した。得られた試料の溶出試験結果を水熱 処理を行わない場合と対比して Fig.7 に示す。フッ素溶出 量は水熱処理を行うことにより低值となっている。また、 $\mathrm{Mo}$ の溶出抑制効果が認められる。 $\mathrm{Zn} 、 \mathrm{Cu}$ についても同様 に溶出は抑制された。灰色 DFA-2 を同様に水熱処理し、溶 出試験を行った結果を Fig.8 に示す。F 以外の $\mathrm{Pb}$ 、全 $\mathrm{Cr}$ 、 Mo において溶出抑制効果が認められる。Zn、Cuについて も同様であった。水熱処理による固定化機構については 5.6 項で述べる。

\section{4 水熱処理における圧力の影響}

DFA-2 を高炉スラグセメント B 種と重量比 $3 / 2$ または 4/1 で混合し、混練後に凝結させた試料について、空気ガスに

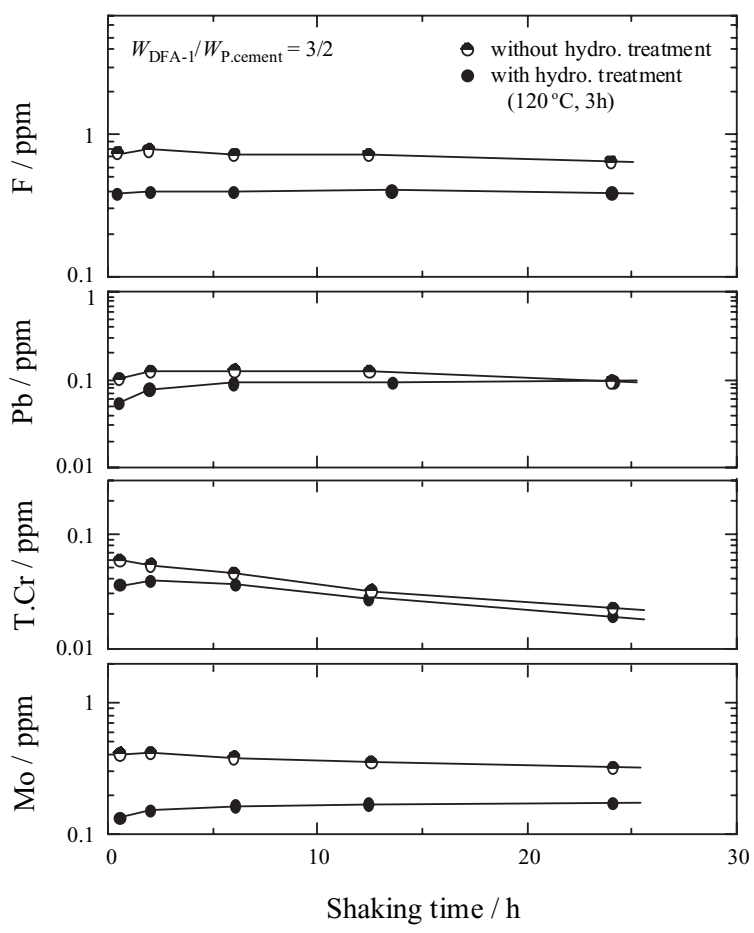

Fig. 7 Effect of hydrothermal treatment on $\mathrm{F}, \mathrm{Pb}$, total $\mathrm{Cr}$ and $\mathrm{Mo}$ immobilization in mixture of DFA-1 and Portland cement.

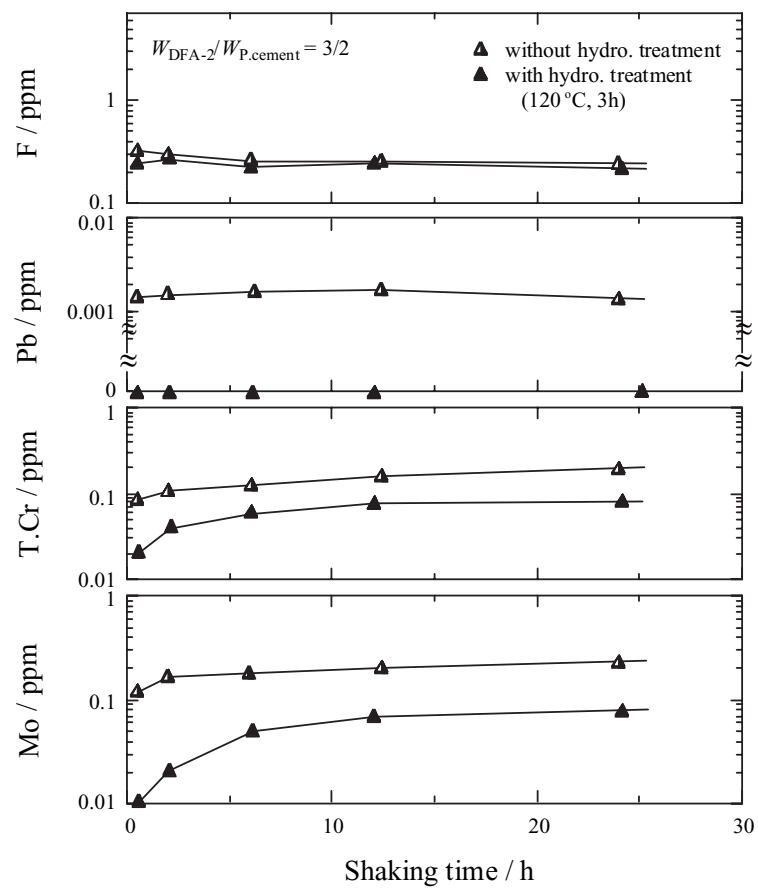

Fig. 8 Effect of hydrothermal treatment on $\mathrm{F}, \mathrm{Pb}$, total $\mathrm{Cr}$ and $\mathrm{Mo}$ immobilization in mixture of DFA-2 and Portland cement.

より $2 \mathrm{MPa}$ に加圧しながら $120^{\circ} \mathrm{C} て ゙ 3 h$ オートクレーブ処理 した。また、外熱式圧粉容器中で $120^{\circ} \mathrm{C} 、 10 \mathrm{MPa}$ に加熱加 圧しながら $3 \mathrm{~h}$ 水熱処理した。得られた試料の溶出試験結 


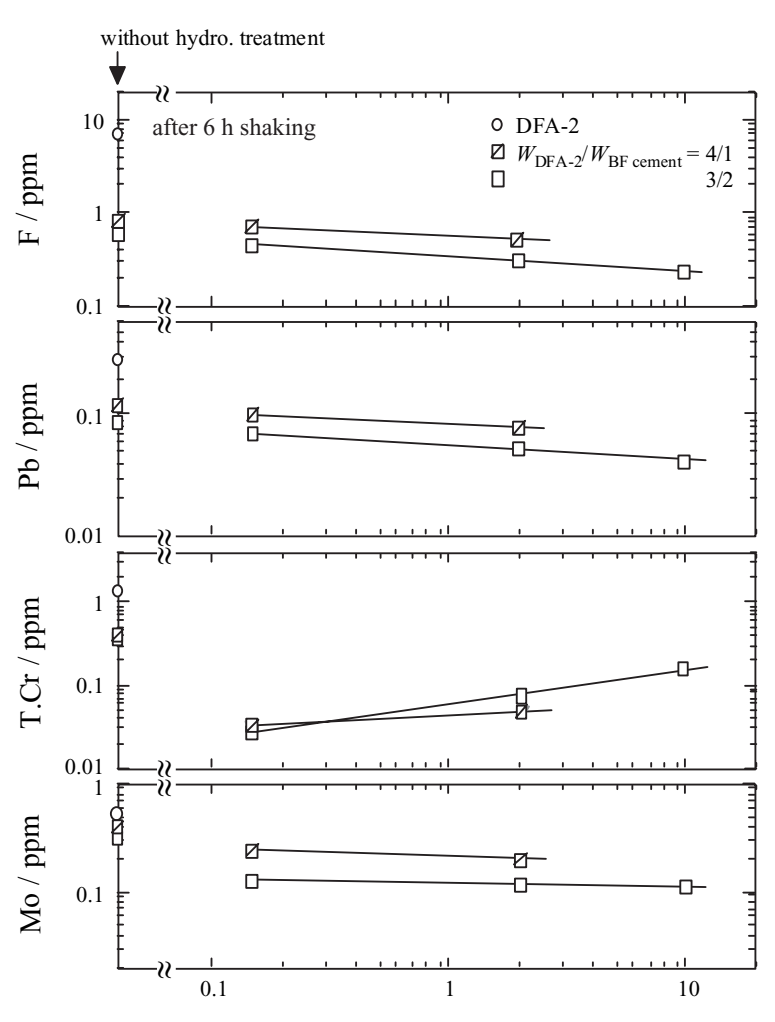

Pressure at hydrothermal treatment / MPa

Fig. 9 Relationship between pressure at hydrothermal treatment and F, $\mathrm{Pb}$, total $\mathrm{Cr}$ and $\mathrm{Mo}$ contents in solution dissolved from mixture of DFA-2 and blast furnace slag cement after $6 \mathrm{~h}$ shaking.

果をFig.9に示す。いずれの図においてもセメント量が多 いほど溶出值は低いが、圧力の影響は小さいことがわかる。 著者らは都市ゴミ焼却灰とセメントを混練し、 $200^{\circ} \mathrm{C} 、 3 \mathrm{~h}$ 処理を行った実験において F、Pb 溶出值が著しく低下する ことを見出している。このことから、水熱反応においては 圧力より温度の寄与が大きいと考えられた。この点につい ては別報で述べる。

\section{5 水熱処理における石膏添加の影響}

水熱反応の際に固定剤に石膏を添加することによ り $\mathrm{AFt}$ 相および $\mathrm{AFm}$ 相の生成が速やかになり、また $\mathrm{CaO}-\mathrm{SiO}_{2}-\mathrm{H}_{2} \mathrm{O}-\mathrm{CaSO}_{4}$ 系化合物および非晶質ゲルが生成する ことから、F 固定化が促進される ${ }^{14)}$ 。そこで、DFA-2 と高 炉スラグセメントB 種に石膏を重量比 4/1/0.5 で混合し、混 練後に凝結させた試料について、 $120^{\circ} \mathrm{C} て ゙ 3 \mathrm{~h}$ オートクレー ブ処理した。その溶出試験結果を Fig.10に示す。いずれの 元素においても、石亮の添加により溶出が抑制されている。

\section{6 カーシュレッダーダスト直接溶融飛灰 / セメントの反 応機構}

4.4 項に述べた方法により、DFA-1 とポルトランドセ メントとの反応界面を観察した。Fig.11はDFA-1 / ポ

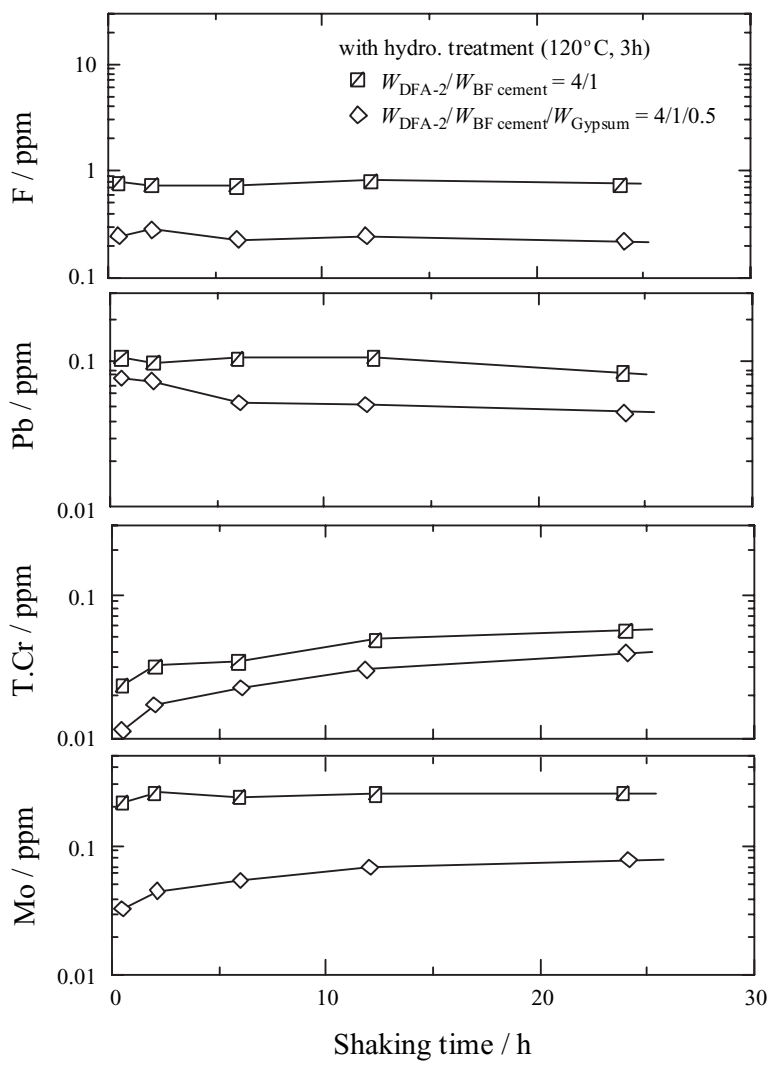

Fig. 10 Effect of gypsum addition to mixture of DFA-2 and blast furnace slag cement on $\mathrm{F}, \mathrm{Pb}$, total $\mathrm{Cr}$ and $\mathrm{Mo}$ immobilization by hydrothermal treatment.

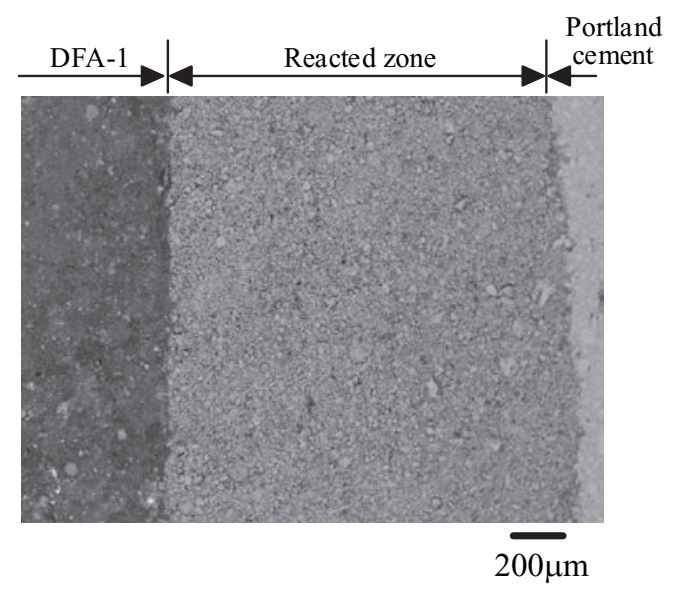

Fig. 11 SEM image of hydrothermally reacted layer at DFA-1/Portland cement interface.

ルトランドセメント界面の SEM 像である。この界面に生 成した層について各成分濃度のCMA(Computer Mapping Analysis) およびEPMA-WDXによる定量分析を行っ た。その結果、 $\mathrm{Ca}_{3} \mathrm{SiO}_{5}-\mathrm{H}_{2} \mathrm{O} 、 \mathrm{Ca}_{2} \mathrm{SiO}_{4}-\mathrm{H}_{2} \mathrm{O} 、 \mathrm{CaSiO}_{3}-\mathrm{H}_{2} \mathrm{O}$ および非晶質ゲルといった $\mathrm{CaO}-\mathrm{SiO}_{2}-\mathrm{H}_{2} \mathrm{O}$ 系水和物相と 
$\mathrm{Ca}_{6}\left[\mathrm{Al}(\mathrm{OH})_{6}\right]_{2}\left(\mathrm{SO}_{4}\right)_{3} \cdot 26 \mathrm{H}_{2} \mathrm{O}$ といった $\mathrm{AFt}$ 相が生成しており、 これらの相中にフッ素が固定化されていることが分かっ た。Pb は Table 1 に示したようにDFA-1 中の濃度が低かっ たため、明らかな傾向は見出せなかった。

セメントによる都市ゴミ焼却灰の固定化においては、焼 却灰の周囲にコンクリートの遮断層ができて溶出が防止さ れることの他に、凝結時に生成する Ettringite、 $\mathrm{Ca}_{6}\left[\mathrm{M}(\mathrm{OH})_{6}\right]_{2}$ $\left(\mathrm{SO}_{4}, \mathrm{RO}_{4}\right)_{3} \cdot m \mathrm{H}_{2} \mathrm{O}$ 中の $\mathrm{M}^{3+}$ サイト、 $\mathrm{RO}_{4}$ サイトと重金属イ オンが置換し ${ }^{15-18)} 、 \mathrm{OH}^{-}$サイトと F-イオンが置換する ${ }^{19)} こ$ とにより固定化が起こることが報告されており、本研究結

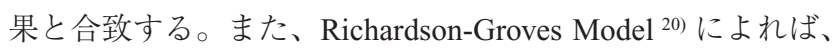
$\mathrm{CaO}-\mathrm{SiO}_{2}-\mathrm{H}_{2} \mathrm{O}$ 系非晶質ゲルによる陽イオンおよび陰イオン の固定化は (1) 式で表される。

$\mathrm{Ca}_{x} \mathrm{H}_{(6 n-2 x)}\left(\mathrm{Si}_{1-a} \mathrm{R}_{a}{ }^{[\mathrm{VV}]}{ }_{(3 n-1)} \mathrm{O}_{(9 n-2)} \cdot \mathrm{A}^{C+}{ }_{a(3 n-1) / C} \cdot z \mathrm{Ca}(\mathrm{OH})_{2} \cdot m \mathrm{H}_{2} \mathrm{O}\right.$

ここで、 $x=0.5(6 n-w) 、 z=0.5\{w+n(y-2)\} 、 0<a<2 / 3 n-1$ であり、 $w$ は $y$ に応じて種々の值となる。(1) 式において $\mathrm{R}$ は四面体配位の 3 価陽イオンであり、 $\mathrm{Al}^{3+} 、 \mathrm{Fe}^{3+} 、 \mathrm{Cr}^{3+}$ 等が 置換する。 $\mathrm{A}^{C+}$ は 1 価または 2 価の陽イオンであり、 $\mathrm{Li}^{+} 、$ $\mathrm{Na}^{+} 、 \mathrm{~K}^{+} 、 \mathrm{Rb}^{+} 、 \mathrm{Cs}^{+} 、 \mathrm{Ca}^{2+} 、 \mathrm{Co}^{2+} 、 \mathrm{Hg}^{2+} 、 \mathrm{Cd}^{2+} 、 \mathrm{~Pb}^{2+} 、 \mathrm{U}^{2+}$ 等が置換する。また、 $\mathrm{OH}^{-}$サイトには $\mathrm{Cl}^{-} 、 \mathrm{I}^{-} 、 \mathrm{~F}^{-} 、 \mathrm{CO}_{3}{ }^{2-} 、$ $\mathrm{SO}_{4}{ }^{2-}$ が置換する。本研究結果による有害物質の固定化は Ettringite と $\mathrm{CaO}-\mathrm{SiO}_{2}-\mathrm{H}_{2} \mathrm{O}$ 系水和物の生成によって説明さ れる。

水熱反応により水和反応が促進されることはよく知ら れている。Nishioka ら 21) は硼珪酸ガラス粉とゴミ焼却灰 をホットプレス法により $300^{\circ} \mathrm{C} 、 25 \mathrm{Mpa}$ で $20 \mathrm{~min}$ 反応させ た結果、重金属の溶出が抑えられたと述べている。本実 験での水熱条件はより低温、低圧であるが、C 濃度が低く 親水性が高い、即ち水和反応しやすい灰色系 DFA-2 にお いて水熱処理効果が明らかであった。さらに、固定剤と してセメントと共に石膏を加え水熱処理を行った試料の鉱 物相を XRD および EPMAにより同定したところ、AFt 相 の増量の他に重金属を含有する $\mathrm{Ca}_{10} \mathrm{Al}_{2} \mathrm{Si}_{4}\left(\mathrm{SO}_{4}\right) \mathrm{F}_{40} \cdot 45 \mathrm{H}_{2} \mathrm{O}$ 相、 $\mathrm{Ca}_{10}\left(\mathrm{SiO}_{4}, \mathrm{SO}_{4}\right)_{3}(\mathrm{OH}, \mathrm{F})_{2}$ 相、 $\mathrm{Ca}_{5}\left[(\mathrm{Si}, \mathrm{S}) \mathrm{O}_{4}\right]_{3}(\mathrm{~F}, \mathrm{OH})$ 相といった $\mathrm{CaO}-\mathrm{SiO}_{2}-\mathrm{H}_{2} \mathrm{O}-\mathrm{CaSO}_{4}$ 系化合物、および $\mathrm{CaO}-\mathrm{SiO}_{2}-\mathrm{H}_{2} \mathrm{O}-\mathrm{CaSO}_{4}$ 系非晶質ゲルの生成が認められたこと から、これら水和物が有害元素の固定化に寄与しているこ とは明らかであった。

\section{6. 結言}

重金属およびフッ素を高濃度に含むカーシュレッダーダ ス卜直接溶融飛灰をセメントおよび水熱反応により無害化 する研究を行った。カーシュレッダーダスト直接溶融飛灰 をポルトランドセメントと混練し凝結させることにより、 有害元素の溶出抑制効果が認められた。また、この凝結体 について水熱処理を行ったところ、有害元素の溶出抑制効
果は上昇した。この傾向は灰色系カーシュレッダーダスト 直接溶融飛灰の場合に顕著であった。セメントに石膏を添 加して水熱処理を施すことにより、有害元素の溶出はさら に抑制された。これらの方法によっても $\mathrm{Pb}$ および Moにつ いては廃棄物処理判定基準はクリアできるものの土壤環境 基準をクリアできておらず、さらなる研究が必要であるが、 本研究では無害化処理物の長期安定性も合わせて評価する ために $0.1 \mathrm{~mm}$ 以下の試料について溶出試験を行っており、 環境庁告示 46 号の方法（試料粒度 $2 \mathrm{~mm}$ 以下）と比べて遙 かに厳しい試験条件であることに留意すべきである。現状 では長期安定性の評価法について統一的な見解が示されて いないが、本研究で用いた溶出量評価法が無害化処理物の 長期安定性を検討する際の一助になれば幸いである。

\section{引用文献}

1) 日本自動車工業界ホームページ http://www.jama.or.jp/lib/jamar eport/081/81_6.html

2) 経済産業省・環境省「家電リサイクル法の施行状況（平成 17 年度取引実績）について」http://www.meti.go.jp/policy/kaden_re cycle/pdf/17fy_recycling_results(set).pdf

3) 特許庁資料室 http://www.jpo.go.jp/shiryou/s_sonota/map/ippan0 3/1/1-3-2.htm

4) 不破敬一郎: 生体と重金属、1981、講談社サイエンティフィク.

5) 角田文男：日本公衆衛生学雑誌、38(1991)Suppl.1, 31-36.

6) 佐藤 勉、丹羽源男：日本臨床、54(1996)67-72.

7) 早川亮太 : 水質污濁研究、13(1990)23.

8) 金子栄廣 : 廃革物学会誌、3(1992)182-191.

9) 水渡英昭、井上＼cjkstart亮：Sanyo Technical Report, 10(2003)9-18.

10) 荒井康夫：セメントの材料科学、1991、大日本図書、東京.

11）セメント・コンクリート用混和材、笠井芳夫 · 小林正几編著、 1993、技術書院、東京.

12) 井上 亮、水渡英昭：鉄と鋼、88(2002)340-346.

13) R. INOUE and H. SUITO: International Conference on Steel and Society, Osaka, 2000, 447-450, ISIJ.

14) R. INOUE and H. SUITO: ISIJ International, 425(2002)930-937.

15) A. KINDNESS, A. MACIAS and F.P.GLASSER : Waste Management, 14(1994)3-11.

16) A. KINDNESS, E.E. LACHOWSKI, A.K. MINOCHA and F.P.GLASSER : Waste Management, 14(1994)97-102.

17) M.L.D. GOUGAR, B.E. SCHEETZ and D.M. ROY : Waste Management, 16(1994)295-303.

18）下田興道：焼却灰・ばいじんの高度処理技術、NTS、1994、 285-298.

19) H.HE and H. SUITO : ISIJ International, 41(2001)506-512;42(2002) 794-799.

20) I.G. RICHARDSON and G.W. GROVES : Cem. \& Concr., Res., 23(1993)131-138.

21) M. Nishioka, K. Yanagisawa and N. Yamasaki : Research Journal WPCF, 62(1990)926-932. 